Левчук О. В., канд. екон. наук, доцент (ORCID 0000-0002-2827-2134); Левчук В. Д. (ORCID 0000-0001-6436-985X)

Центр воєнно-стратегічних досліджень Національного університету оборони України імені Івана Черняховського, Київ

\title{
Аналіз нормативно-правової бази здійснення оборонних закупівель
}

Резюме. Розглянуто ключові аспекти правил і процедур здійснення оборонних закупівель. Охарактеризовано особливості впливу корупції на оборонні закупівлі та методи протидії ії негативним наслідкам. Визначено основні способи виявлення корупційної складової в державних оборонних закупівлях і їх вплив на безпеку країни в економічній сфері. Проаналізовано нормативно-правову базу здійснення оборонних закупівель.

Ключові слова: державні оборонні закупівлі; корупція; державне оборонне замовлення; євроатлантична інтеграція; матеріально-технічне забезпечення військ; оптимізація процесу оборонних закупівель; засекречені закупівлі; комплексне дослідження ринку.

Постановка проблеми. Актуальність обраної теми дослідження зумовлена тим, що для ефективного розвитку сектору оборони в умовах євроатлантичної інтеграції, переходу Збройних Сил України на стандарти НАТО та забезпечення кращого спрямування ресурсів для захисту держави, питання мінімізації корупційної складової в процесі здійснення оборонних закупівель потребують детального вивчення з погляду прозорості та підвищення ефективності контролю.

Так, згідно з Індексом антикорупційної політики в оборонному секторі, розробленому міжнародною організацією Transparency International, український сектор оборони отримав загальну оцінку “D”, що свідчить про низький рівень прозорості та "високий” рівень корупційного ризику [6]. Оборонні закупівлі отримали доволі низькі бали від міжнародних експертів, i були відмічені як найбільш непрозора та вразлива до корупції сфера в оборонному секторі. За офіційними даними, річний бюджет Міністерства оборони України за 2018 рік складає 86,6 млрд грн (2,8 млрд євро) [3]. Із них бюджет закупівель оборонного відомства складає 32,7 млрд грн (приблизно 1 млрд євро). Загалом слід зазначити, що більше $55 \%$ закупівельного бюджету використовується для закупівель за закритою процедурою, а закупівля озброєння та військової техніки на $95 \%$ є засекреченою. Утім, у разі наявності корупційної складової у закритій закупівлі, за різними оцінками, від 5 до $40 \%$ бюджету такої закупівлі може розкрадатися.

Аналіз

останніх

досліджень.

Проблемні питання виникнення та подолання корупції, методів протидії цьому явищу, вплив корупції на економічну безпеку країни загалом досліджували у своїх наукових працях низка провідних вчених, зокрема, В. Бутенко, 3. Варналій, С. Дубенко, В. Каспрук, Г. Кохан, О. Прохоренко, С. Серьогін, І. Шевчук та ін. [9, 10]. Утім, в інтересах забезпечення національної безпеки питання мінімізації корупційних ризиків в оборонній сфері потребують детальнішого вивчення.

Метою дослідження $є$ вивчення впливу корупції на процес здійснення оборонних закупівель в Україні та методів протидії негативним наслідкам цього явища.

Виклад основного матеріалу. Досягненню поставленої мети підпорядковано такі завдання:

дослідити вплив корупційної складової на процес здійснення оборонних закупівель;

визначити основні заходи виявлення корупційної складової в процесі державних оборонних закупівель та мінімізувати іiі негативний вплив на безпеку країни в економічній сфері;

проаналізувати нормативно-правову базу здійснення оборонних закупівель.

У Законі України "Про запобігання корупції” від 14 жовтня 2014 року корупиію визначено як "використання особою, зазначеною у частині першій ст. 3 Закону, наданих їй службових повноважень чи пов'язаних 3 ними можливостей 3 метою одержання неправомірної вигоди або прийняття такої вигоди чи прийняття обіцянки/пропозиції такої вигоди для себе чи інших осіб або відповідно обіцянка/пропозиція чи надання неправомірної вигоди особі, зазначеній у частині першій ст. 3 Закону, або на ii вимогу іншим фізичним чи юридичним 
особам 3 метою схилити цю особу до протиправного використання наданих їй службових повноважень чи пов'язаних з ними можливостей” [1].

Аналіз низки визначень поняття “корупція" дає змогу виокремити загальні ознаки цього явища, до яких можна віднести: взаємні зобов' язання;

прийняття рішень, що суперечать моральним принципам або порушують чинне законодавство;

взаємна вигода;

свідоме підпорядкування суспільних інтересів особистій вигоді; сторін; отримання певних преференцій для обох намагання обох сторін приховати свої діï.

Утім, корупцію можливо виявити та мінімізувати іiі вплив. Найчастіше корупційні схеми можуть бути складними та непрозорими, однак у процесі детальнішого вивчення в них чітко простежуються типові практики та ознаки неправомірних дій, тому доцільно акцентувати увагу на таких питаннях:

на які фактори слід звернути особливу увагу під час прийняття рішення щодо закупівлі продукції оборонного призначення для уникнення корупційної складової;

встановити чіткі набори даних щодо запобігання найбільш поширеним різновидам корупції.

Слід зазначити, що чинний процес закупівель для потреб оборони впродовж тривалого часу був непрозорим. Значна частина закупівель була засекреченою на термін від 5 до 30 років. Згідно 3 Індексом антикорупційної політики в оборонному секторі, найоптимальнішим $є$ варіант засекречування, в середньому від 1 до $5 \%$ відсотків витрат на оборону [6].

Вітчизняний досвід процесу здійснення державних оборонних закупівель потребує кардинальних i термінових реформ. Наприклад, за допомогою міжнародних експертів і громадянського суспільства в Міністерстві оборони Республіки Грузія впродовж 2013-2015 pp. внаслідок проведення низки реформ i збільшення прозорості вдалось зменшити обсяг засекречених витрат з $90 \%$ до $6 \%$ [7]. Проте між даними, які оприлюднює Міністерство оборони щодо секретних i публічних закупівель, спостерігаються значні розбіжності, тому доводиться визнати, що стосовно засекречених державних оборонних закупівель інформація щодо питань забезпечення національної безпеки, як-от конкретні технічні вимоги для унікальних зразків озброєнь, практично відсутня.

Законом України "Про Державний бюджет України на 2019 рік” Міністерству оборони передбачено 102,5 млрд грн (2,6\% ВВП), а саме: 101,7 млрд грн - Міністерству оборони та 0,8 млрд грн - Державній спеціальній службі транспорту, що входить до складу Міноборони. Ці видатки проти 2018 року збільшено на 10,9 млрд грн, або на $12 \%$ [3]. Видатки на грошове утримання військовослужбовцям складуть 49,6 млрд грн. Також передбачено збільшення не менш ніж на $30 \%$ розмірів грошового забезпечення військовослужбовців, оснащення військ сучасними зразками озброєння та військової техніки, матеріально-технічне забезпечення військ, насамперед, залучених в Операції Об'єднаних Сил (ООС). На державне оборонне замовлення у наступному році 3 Державного бюджету може бути спрямовано до 25 млрд грн. Ці кошти передбачено спрямувати на закупівлю зброї та техніки, а також на виконання дослідно-конструкторських робіт 3 розроблення нових зразків ОВТ [8].

3 огляду на наведені вище дані та для оптимізації процесу оборонних закупівель, а саме усунення корупційної складової, варто було б звернути особливу увагу на:

підприємства, 3 якими укладено контракт на постачання (виробництво, удосконалення, ремонт ОВТ) поза конкуренцією;

тип процедури, яку було обрано для завершення торгів (конкурентну, переговорну, прямий контракт з одним постачальником);

правові критерії, на основі яких обрано виняток iз конкурентних торгів; правові причини вибору переговорної процедури або прямих закупівель;

стандарти допуску до торгів, методичні вказівки для процесу відбору, включно 3 інформацією щодо процедури оцінювання заявок постачальників;

механізм оцінювання Міністерством оборони вартості товарів або послуг під час оголошення тендеру або запрошенні учасника торгів, включно 3 інформацією про ринкову ціну, яку було покладено в основу оцінювання оголошеної вартості, включаючи засекречені закупівлі;

назви юридичних осіб учасників та переможців торгів (опубліковані після підписання контракту), номер контракту, номер змін до контракту, опис замовлених товарів i послуг, тривалість тендерної процедури, 
передбачений тендером час між підписанням контракту та запланованим часом його виконання, вартість контракту, укладеного 3 переможцем торгів, імена підрядників, агентів та консультантів, найнятих для виконання контракту;

опубліковане підтвердження від голови тендерного комітету щодо відповідності компанії-переможця всім кваліфікаційним вимогам;

критерії вибору переможця, застосовані до пропозицій та обгрунтування вибору переможця;

імена та посади держслужбовців, які відігравали формальну чи неформальну роль в ухваленні рішень, а також публічне підтвердження від тендерного комітету Міністерства оборони щодо кожного тендеру стосовно того, що кожна особа, пов'язана зі складанням тексту або процесу закупівлі, яка має конфлікт інтересів, була виявлена та виключена з процесу ухвалення рішень;

загальна вартість контрактів, укладених iз кожним постачальником, сумарні вартості контрактів за 3 або 12 місяців, дати контрактів 3 іменами посадових осіб, які підписували контракти;

підписаний контракт (завантажений в електронну систему як додаток) та будь-які переглянуті контракти, із зазначенням погоджених змін у ціні, даті виконання та будь-яких змінах в умовах після підписання контракту.

Як показує міжнародний досвід у сфері оборонних закупівель, конкуренція в умовах вільного ринку може бути свідомо обмежена. Наприклад, у разі, коли на конкурентному ринку занадто мало учасників подають заяви на участь у тендері, або одному з учасників занадто часто надають перевагу. Це може свідчити про змову, тобто корупційну домовленість між компаніями задля свідомого обмеження конкуренції під час торгів.

Оскільки, відповідно до Закону України "Про державне оборонне замовлення", державні замовники з оборонного замовлення - це визначені Кабінетом Міністрів України центральні органи виконавчої влади, інші державні органи головні розпорядники бюджетних коштів (зокрема Міністерство оборони), військові формування, утворені відповідно до законів України, вони також потенційно можуть брати участь у домовленостях щодо свідомого обмеження конкуренції [4].

Для запобігання появі корупційної змови під час здійснення оборонних закупівель, постачання Збройним Силам України завідомо неякісної продукції (робіт, послуг), свідомого обмеження конкуренції в закупівлях, відповідно до ст. 4 Закону України "Про державне оборонне замовлення" державний замовник (Міністерство оборони) [4]:

здійснює планування оборонного
замовлення;
готує і подає уповноваженому органу 3 питань координації оборонного замовлення пропозиції до проєкту основних показників оборонного замовлення на відповідний бюджетний період;

укладає державні контракти 3 виконавцями;

організовує та здійснює процес закупівлі; забезпечує фінансування відповідно до умов державних контрактів;

здійснює контроль за цільовим використанням бюджетних коштів, виділених на виконання оборонного замовлення відповідно до умов державних контрактів;

здійснює контроль за ходом виконання робіт (на окремих етапах та загалом) згідно 3 оборонним замовленням;

надає виконавцеві технічне завдання та погоджує 3 ним техніко-економічні показники оборонної продукції (робіт, послуг);

у разі одержання в установленому законодавством порядку повноважень на право здійснення імпорту товарів військового призначення і товарів, що містять відомості, що становлять державну таємницю, може укладати договори (контракти) з оборонного замовлення на постачання (закупівлю) продукції, робіт і послуг оборонного призначення за імпортом або уповноважувати на укладання таких договорів (контрактів) виключно для забезпечення потреб державного замовника суб’єкта господарювання, що належить до сфери його управління.

Крім того, Замовник повинен мати обгрунтовані підстави для зменшення конкуренції або укладання контрактів напряму. Наприклад, Замовник може обрати тільки одного постачальника певного продукту, закупівля якого є терміновою, або з міркувань національної безпеки отримана технологія має надходити 3 надійного джерела. Так, згідно 3 даними Transparency International, в Україні такими винятками зловживають найчастіше, оскільки значна кількість контрактів укладається 3 мінімальною або без жодної конкуренції, та підпадає під дію Закону України "Про державну таємницю" [2]. У такому разі обгрунтування вибору 
постачальника підлягає перевірці 3 боку громадськості або контролюючих органів. Отже, найбільш розповсюдженими загрозами під час укладання контрактів у сфері оборонних закупівель $€$ :

великий відсоток контрактів, укладених

3 одним постачальником;

участь у тендері меншої кількості

учасників, ніж очікувалось;

стислий термін подання заявок щодо

участі у тендері;

прийняття заяви від учасника торгів, яка

невигідна постачальнику;

заявки учасників тендеру відповідають

усім вимогам, але згодом можуть бути

відхилені з незрозумілих причин;

укладання Замовником контракту 3

єдиним постачальником за наявності інших,

економічно вигідних, доречних чи передбачуваних пропозицій;

завуальована схема вигравання тендерів по черзі двома чи більшою кількістю постачальників;

подання завідомо неповних, некоректних, неконкурентних заявок щодо участі у тендері.

Відповідно до ст. 3 Закону України "Про особливості здійснення закупівель товарів, робіт і послуг для гарантованого забезпечення потреб оборони", в разі прийняття Замовником рішення про застосування переговорної процедури закупівлі, відбір учасників здійснюється через електронну систему закупівель у порядку, визначеному Законом [5].

Крім того, одночасно 3 розміщенням оголошення про проведення відбору, Замовник може оприлюднити проєкт договору про закупівлю. Тут слід зауважити, що технічні, якісні та кількісні характеристики предмета закупівлі та кваліфікаційні критерії до учасників відбору не можуть містити дискримінаційних умов і зменшувати рівень конкуренції. Документи, що підтверджують набір характеристик і критеріїв, зазначених в абзаці 1 частини 6 Закону України "Про особливості здійснення закупівель товарів, робіт і послуг для гарантованого забезпечення потреб оборони”, подаються учасником відбору самостійно.

Оголошення про проведення тендерної процедури на здійснення оборонних закупівель обов'язково оприлюднюється через авторизовані електронні майданчики вебпорталу Уповноваженого органу англійською мовою, якщо очікувана вартість закупівлі перевищує суму: для товарів і послуг - 35 тис. євро; для робіт - 1500 тис. євро.

Слід також звернути особливу увагу на те, що в разі обрання Замовником критеріїв оцінки, зазначених у пункті 1 частини 8 Закону України "Про особливості здійснення закупівель товарів, робіт і послуг для гарантованого забезпечення потреб оборони", приведена ціна розраховується електронною системою закупівель з урахуванням показників таких критеріїв оцінки за математичною формулою, наведеною в оголошенні про проведення відбору.

Однак у разі здійснення закупівлі, яка має складний або спеціалізований характер (консультаційних послуг, наукових досліджень, експериментів, розробок, дослідноконструкторських робіт) доцільно врахувати вимоги п. 2 частини 8 цього Закону, відповідно до якої ціна $\epsilon$ основним ваговим показником (питома вага цього критерію не може бути нижчою, ніж $70 \%$ ) разом 3 іншими критеріями оцінки, зокрема:

умови оплати;

строк виконання контракту;

гарантійне обслуговування;

експлуатаційні витрати;

загальна вартість користування

(життєвий цикл);

передача технології та підготовка управлінських, наукових і виробничих кадрів, включаючи використання місцевих ресурсів, зокрема засобів виробництва, робочої сили та матеріалів для виготовлення товарів, виконання робіт, надання послуг, що пропонуються учасником.

Проте у разі здійснення закупівлі товарів, робіт, послуг, що виробляються, виконуються чи надаються не за окремо розробленою специфікацією (технічним проєктом), для яких існує постійно діючий ринок, єдиним критерієм оцінки $€$ ціна.

Висновки. Підсумовуючи наведене вище, слід наголосити, що непрозорість суттєво підвищує ризик корупції у засекречених закупівлях. Так, публікація відповідних даних щодо публічних і засекречених закупівель $\epsilon$ звичною практикою для багатьох інших держав, таких як США, Велика Британія та Нідерланди. Вважаємо, що під час здійснення оборонних закупівель варто розробити методичні рекомендації щодо проведення комплексного дослідження цього ринку до початку проведення тендеру, в яких доцільно врахувати технічні вимоги оборонної продукції (робіт, послуг), техніко-економічні характеристики та економічне обгрунтування 
доцільності обрання певного товару, механізм проведення внутрішньої перевірки учасників торгів та засекречування інформації.

Крім того, відповідно до міжнародних стандартів, для всіх закупівель, включно із засекреченими, Міністерство оборони має опублікувати впродовж 20 днів після оголошення переможця таку інформацію:

1. Назви учасників та переможців торгів (після оголошення результатів тендерів), номери контрактів, номери змін до контрактів, опис закупівель, тривалість оголошення тендеру, тривалість виконання умов контракту, остаточна ціна угоди (опублікована у відкритому доступі одразу після оголошення тендеру);

2. Загальна кількість угод, укладених із кожним постачальником, загальна вартість таких контрактів упродовж 3 або 12 місяців, дати оголошення результатів та відповідальних осіб. консультантів, яких було залучено для виконання контракту.

Практичне впровадження таких рекомендацій забезпечить оптимізацію процесу здійснення оборонних закупівель, ефективне використання бюджетних коштів, ïx цільове використання та позитивно вплине України.
3. Імена підрядників, агентів та на посилення обороноздатності Збройних Сил

\section{СПИСОК ВИКОРИСТАНОЇ ЛІТЕРАТУРИ}

1. Про запобігання корупції: Закон України [Електронний ресурс] - Режим доступу: https://zakon.rada.gov.ua/laws/show/1700-18.

2. Про державну таємницю: Закон України [Електронний ресурс] - Режим доступу: https://zakon.rada.gov.ua/laws/show/3855-12.

3. Про Державний бюджет України на 2019 рік: Закон України [Електронний ресурс] - Режим доступу: https://zakon.rada.gov.ua/laws/show/269619.

4. Про державне оборонне замовлення: Закон України [Електронний ресурс] - Режим доступу: https://zakon.rada.gov.ua/laws/show/464-14.

5. Про особливості здійснення закупівель товарів, робіт, послуг для гарантованого забезпечення потреб оборони: Закон України [Електронний ресурс] - Режим доступу: https://zakon.rada.gov.ua/laws/show/1356-19.

6. Україна, Індекс антикорупційної політики в оборонному секторі, Transparency International, [Електронний pecypc] - Режим доступу: http://government.defenceindex.org/countries/Ukraine

7. Грузія, Q.24, Індекс антикорупційної політики в оборонному секторі, Transparency International, [Електронний pecypc] - Режим доступу: https://www.transparency.org/country/GEO.

8. Офіційний сайт Міністерства оборони України. URL: https://mil.gov.ua/news.

9. Прохоренко О.Я. Корупція по-українськи (сутність, стан, проблеми): монографія / О.Я. Прохоренко. - К.: Вид-во НАДУ, 2005. - 456 с.

10. Серьогін С.C. Механізми попередження та протидії корупції в органах публічної влади [Електронний pecypc]. - Режим доступу: http://nbuv.gov.ua/UJRN/Unzap_2009_4_51.

Стаття надійшла до редакційної колегії 18.06.2019

Левчук Е. В., канд. экон. наук, доцент;

Левчук В. Д.

Центр военно-стратегических исследований Национального университета обороны Украины имени Ивана Черняховского, Киев

\section{Анализ нормативно-правовой базы осуществления оборонных закупок}

Резюме. Рассмотрены ключевые аспекты правил и процедур проведения оборонных закупок. Охарактеризованы особенности влияния коррупции на оборонные закупки и методы противодействия его негативным последствиям. Определены основные способы выявления коррупционной составляющей в государственных оборонных закупках и их влияние на безопасность страны в экономической сфере. Проанализирована нормативно-правовая база осуществления оборонных закупок.

Ключевые слова: государственные оборонные закупки; коррупция, государственный оборонный заказ; евроатлантическая интеграция; материально-техническое обеспечение войск; засекреченные закупки; комплексное исследование рынка.

\section{O. Levchuk, PhD (Economic), assistant professor ;}

\section{Levchuk}

Center for Military and Strategic Studies of the National Defence University of Ukraine named after Ivan Cherniakhovskyi, Kyiv

Analysis of the legal framework for the implementation of defense procurement

Resume. Covered key aspects of the rules and procedures of defense procurement. The features of the impact of corruption on defence procurement and methods to counter its negative consequences. The main ways to detect corruption component in the state defense procurement and its impact on the security of the country in the economic sphere. It analyzed the legal framework of defense procurement.

Keywords: state defense procurement; corruption, state defense order; Euro-Atlantic integration; logistics of the troops; classified procurement; comprehensive market research. 